\title{
IMPLEMENTASI METODE PROFILE MATCHING UNTUK MENGETAHUI SUPPLIER TERBAIK PADA PT. LAUTAN LUAS MEDAN
}

\author{
Muhardi Saputra*, Andre Ongario, Handy Wiryanata Christ Boy Ciam \\ Program Studi Sistem Informasi Fakultas Teknologi dan Ilmu Komputer Universitas Prima Indonesia \\ E-mail: * Shot.jos1@gmail.com
}

\begin{abstract}
ABSTRAK- Supplier merupakan salah satu bagian terpenting dalam suatu perusahaan penyedia jasa konstruksi. Untuk mendapatkan hasil yang terbaik, dibutuhkan pula supplier yang terbaik dan berkualitas. Salah satu upaya untuk mendapatkan supplier tersebut adalah dengan melakukan pemilihan supplier, oleh karena itu pemilihan supplier sangat diperlukan untuk perusahaan penyedia jasa konstruksi. Karena banyaknya supplier, PT. Lautan Luas Medan kesulitan dalam memilih supplier dengan kelebihannya masing-masing. Proses pemilihan supplier ini menggunakan metode Profile Matching, dengan tahapan yaitu menentukan kriteria, perhitungan pemetaan gap, melakukan pembobotan, perhitungan core factor yang dan secondary factor, perhitungan nilai total, dan perhitungan untuk menentukan perangkingan. Kriteria pemilihan supplier pada PT. Lautan Luas Medan adalah pengiriman, pelayanan, produk, kualitas dan harga. Pemilihan supplier dengan metode Profile Matching ini dibangun dengan menggunakan bahasa pemrograman Visual Studio 2010 dan SQL Server 2008. Profile Matching merupakan solusi yang terbaik untuk memecahkan permasalahan dan membantu pimpinan dalam mengambil keputusan pemilihan supplier yang lebih obyektif pada PT. Lautan Luas Medan. Kata kunci : Pemilihan, Supplier Terbaik, Profile Matching
\end{abstract}

\section{PENDAHULUAN}

PT. Lautan Luas yang merupakan sebuah perusahaan yang bergerak dalam bidang produksi dan perdagangan bahan-bahan kimia. Perusahaan ini dalam penyediaan bahan baku produksi maupun produk yang akan diperjualbelikan memiliki banyak pemasok (supplier). Perusahaan sebelum memutuskan supplier yang akan menjadi pemasok produk, terlebih dahulu melakukan penilaian sehingga dapat diperoleh supplier terbaik. Pemilihan supplier terbaik dilakukanagar dapat diperoleh pemasok yang paling sesuai dengan kriteria yang ditetapkan perusahaan, baik dari segi kualitas, kuantitas, harga dan ketepatan waktu pengiriman.Proses pemilihan pemasok terbaik dilakukan dengan penghitungan yang manual, yaitu menjumlahkan semua nilai kepentingan (kriteria) supplier terbaik yang ditetapkan perusahaan. Di mana supplier yang memilikijumlahnilaitertinggi akan berhak sebagai supplier terbaik. Penggunaan sistem manual menghasilkan informasi tidak akurat, sehingga perlu sistem baru barbasis komputerisasi. ${ }^{\text {[9] }}$

Aplikasi pemilihan supplier terbaik ini dirancang menggunakan metode Profile Matching. Metode ini membantu pihak manajemen dalam menilai supplier dengan beberapa aspek dan kriteria yang telah di tentukan dan penilaiannya akan menjadi lebih obyektif dan akurat sehingga bisa menjadi bahan acuan pertimbangan manajemen dalam memilih supplier terbaik. Berdasarkan uraian tersebut, maka dilakukan penelitian dengan judul "Implementasi Metode Profile Matching Untuk Mengetahui Supplier Terbaik Bahan Kimia pad PT. Lautan Luas Medan".

\section{ISI PENELITIAN}

PT Lautan Luas Tbk didirikan dengan nama Perusahan Andil Maskapai Dagang dan Industri Lim Teck Lee (Indonesia) berdasarkan Akta No.75 pada tanggal 18 Januari 1951 oleh Notaris Raden Mas Soerojo. Akta pendirian ini telah disahkan oleh Menteri Kehakiman dengan Surat Keputusan No.J.A.8/13/9.tanggal 13 juli 1951 dan diumumkam dalam Berita Negara No.16 tanggal 22 Februari 1952, Tambahan No.212 dan setelah itu Perseroan memulai kgiatan secara komersiil. Perubahan nama menjadi PT Lautan Luas dilakukan berdasarkan Akta No.90 pada tanggal 20 Desember 1964 atas Wakil Notaris Lie Sioe Hoa Nio dan telah disahkan oleh Menteri Kehakiman dengan Surat keputusan No. J.A 5/24/20 tanggal 20 April 1965.

Dalam rangka penawaran umum, seluruh anggaran dasar Perseroan telah diubah dengan akta no 116 tertanggal 27 Maret 1997 dibuat dihadapan Frans Elsius Muliawan Sarjana Hukum, Notaris di Jakarta yang telah dibuat Data Akta Perubahan Anggaran Dasar Perseroan dibuat oleh Frans Muliawan, Sarjana Hukum, Notaris di Jakarta, tanggal 31 Maret 1997 akta ini dan Data Akta Perubahan Anggaran Dasar Perseroan berturut-turut:

1. Telah disetujui oleh Menteri Kehakiman RI, berdasar surat keputusan Menteri Kehakiman RI no. C2-2490NT.04.Th 97 tertanggal 7 April 1997,yang telah didaftarkan di Daftar Perusahaan Jakarta Barat di bawah no.197/BH.09.03/IV/1997 tertanggal 11 April 1997.

2. Telah diberitahukan kepada Menteri Kehakiman Republik RI tertanggal 11 April 1997.

Metode penelitian yang digunakan pada PT Lautan Luas Medan adalah sebagai berikut: 


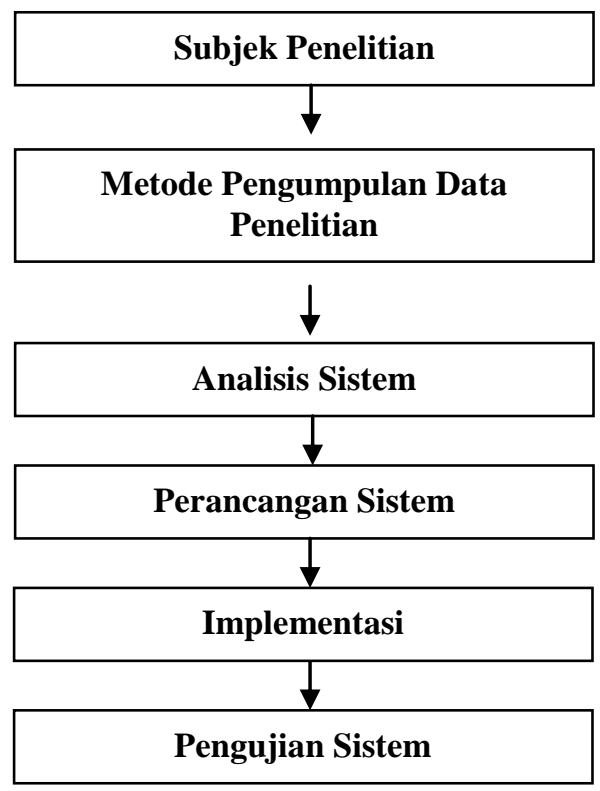

Gambar 1. Kerangka Penelitian

Keterangan Gambar 1:

1. Subjek Penelitian

Subjek yang digunakan dalam penelitian ini adalah pembuatan aplikasi untuk menentukan supplier terbaik dengan menggunakan metode profile matching.

2. Metode Pengumpulan Data

Metode pengumpulan data yang digunakan dalam penelitian ini adalah sebagai berikut:

a. Studi Pustaka

Studi pustaka dilakukan untuk memperoleh data sebagai bahan acuan yang akan digunakan dalam implementasi aplikasi yang dibuat, baik dari buku, jurnal, maupun bahan referensi lainnya yang memiliki relevansi dengan penelitian yang dilakukan[1].

b. Wawancara

Wawancara merupakan metode pengumpulan data dengan mengajukan pertanyaanpertanyaan tentang sistem yang sedang berjalan dengan segala kekurangan sebagai kajian dalam pembuatan program aplikasi yang akan diajukan sebagai sistem yang baru.

c. Observasi

Metode ini merupakan pengamatan langsung yang dapat mempermudah dalam proses pengumpulan data, sehingga data-data yang didapat terjamin keaslian dan kebenarannya. Pengamatan langsung dilakukan pada bagian Pembelian perusahaan dengan mengadakan pencatatan terhadap dokumen-dokumen yang ada serta berkaitan dengan pemilihan supplier terbaik yang diterapkan perusahaan.[8]

3. Analisis Sistem

Analisa sistem digunakan untuk melakukan analisis permasalahan sistem yang akan dibuat mencakup data yang dibutuhkan serta pendeskripsian data sehingga dapat diperoleh proses kerja sistem yang akan dikembangkan secara manual, serta kelebihan dan kelemahannya agar dapat diajukan sedabagi dasar pembuatan sistem yang baru.

4. Perancangan Sistem

Perancangan sistem dilakukan untuk merancang sistem yang baru mencakup proses kerja sistem yang baru, perancangan antar muka program dan perancangan database menggunakan unified modeling language.

5. Implementasi

Implementasi sistem digunakan untuk mengimplementasikan aplikasi yang dibuat ke dalam bahasa pemograman yang digunakan yaitu Visual Studio 2010 sehingga bisa menjadi sebuah sistem baru yang sesuai dengan tujuan penelitian.

6. Pengujian Sistem

Pengujian sistem dilakukan untuk menguji sistem yang dibuat sehingga dapat diketahui bahwa sistem sudah dapat bekerja sesuai yang diharapkan serta tidak ada lagi debug program. Pengujian sistem dilakukan dengan menggunakan metode black box test.

\subsection{Landasan Teori}

1. Sistem Pendukung Keputusan

Sistem pendukung keputusan merupakan suatu sistem sistem interaktif berbasis komputer yang membantu pengambil keputusan memanfaatkan data dan model untuk menyelesaikan masalah masalah yang tidak terstruktur[2].

2. Profile Matching

Metode profile matching atau pencocokan profil adalah metode yang sering sebagai mekanisme dalam pengambilan keputusan dengan mengasumsikan bahwa terdapat tingkat variable prediktor yang ideal yang harus dipenuhi oleh subyek yang diteliti, bukannya tingkat minimal yang harus dipenuhi atau dilewati[2].

Dalam proses profile matching secara garis besar merupakan proses membandingkan antara nilai data aktual dari suatu profile yang akan dinilai dengan nilai profil yang diharapkan, sehingga dapat diketahui perbedaan kompetensinya (disebut juga gap), semakin kecil gap yang dihasilkan maka bobot nilainya semakin besar yang berarti memiliki peluang lebih besar untuk direkomendasikan untuk terpilih dalam hal ini pada proses promosi jabatan[3].

\section{HASIL DAN PEMBAHASAN}

Data penelitian ini dikumpulkan melalui metode kuisioner. Kuisioner dilakukan kepada 5 (orang) yaitu bagian Pembelian, bagian Logistik, bagian Quality Control, bagian Gudang dan bagian keuangan. 
Tabel 1. Rekap Hasil Kuisioner per Supplier

\begin{tabular}{|c|c|c|c|c|c|c|c|c|c|c|c|c|c|}
\hline \multirow{2}{*}{$\begin{array}{l}\mathbf{N} \\
\mathbf{0}\end{array}$} & \multirow{2}{*}{$\begin{array}{l}\text { NaraS } \\
\text { umber }\end{array}$} & \multicolumn{3}{|c|}{ Cost } & \multicolumn{3}{|c|}{ Quality } & \multicolumn{3}{|c|}{ Delivery } & \multicolumn{3}{|c|}{ Services } \\
\hline & & 1 & 2 & 3 & 4 & 5 & 6 & 7 & 8 & 9 & 1 & 4 & 1 \\
\hline 1 & $\begin{array}{l}\text { Pembe } \\
\text { lian }\end{array}$ & 4 & 4 & 3 & 4 & 4 & 3 & 3 & 4 & 3 & 3 & 3 & 4 \\
\hline 2 & $\begin{array}{l}\text { Logisti } \\
\text { k }\end{array}$ & 4 & 3 & 4 & 3 & 4 & 3 & 3 & 4 & 4 & 4 & 4 & 4 \\
\hline 3 & $\begin{array}{l}\text { Qualit } \\
\text { y } \\
\text { Contro } \\
\text { l }\end{array}$ & 5 & 4 & 3 & 4 & 5 & 3 & 3 & 3 & 3 & 4 & 4 & 4 \\
\hline 4 & $\begin{array}{l}\text { Gudan } \\
\text { g }\end{array}$ & 4 & 4 & 4 & 4 & 3 & 4 & 3 & 3 & 4 & 3 & 3 & 3 \\
\hline 5 & $\begin{array}{l}\text { Keuan } \\
\text { gan }\end{array}$ & 4 & 3 & 3 & 3 & 3 & 3 & 3 & 4 & 4 & 3 & 4 & 3 \\
\hline \multicolumn{2}{|c|}{ Total } & $\begin{array}{l}2 \\
1\end{array}$ & $\begin{array}{l}1 \\
8\end{array}$ & $\begin{array}{l}1 \\
7\end{array}$ & $\begin{array}{l}1 \\
8 \\
\end{array}$ & $\begin{array}{l}1 \\
9 \\
\end{array}$ & 4 & $\begin{array}{ll}1 \\
5\end{array}$ & $\begin{array}{l}1 \\
8 \\
\end{array}$ & $\begin{array}{ll}1 \\
8 \\
\end{array}$ & $\begin{array}{ll}1 \\
7\end{array}$ & 8 & $\begin{array}{l}1 \\
8 \\
\end{array}$ \\
\hline \multicolumn{2}{|c|}{$\begin{array}{l}\text { Rata-Rata } \\
\text { Item }\end{array}$} & $\begin{array}{r}4 . \\
2 \\
0\end{array}$ & 0 & $\begin{array}{l}3 \\
\dot{4} \\
0\end{array}$ & 3 & $\begin{array}{l}3 \\
\dot{8} \\
0\end{array}$ & 3 & $\begin{array}{l}3 \\
\dot{0} \\
0\end{array}$ & 3 & $\begin{array}{l}3 \\
\dot{6} \\
0\end{array}$ & $\begin{array}{l}3 \\
\dot{4} \\
0\end{array}$ & 3 & 3 \\
\hline \multicolumn{2}{|c|}{$\begin{array}{l}\text { Rata-Rata } \\
\text { Variabel }\end{array}$} & \multicolumn{3}{|c|}{7} & \multicolumn{3}{|c|}{4} & \multicolumn{3}{|c|}{3} & \\
\hline
\end{tabular}

Berdasarkan hasil pada Tabel 1 di atas dapat dilihat bahwa nilai hasil kuisioner yang disebarkan kepada responden per variabel untuk setiap supplier dapat di hitung total nilai, nilai ratarata per item serta bnilai rata-rata per variabel dengan melakukan perhitungan berikut:

Misalkan Supplier 3 adalah SP_001, SP_002, SP_003.

Variabel $5=$ Cost, Quality, Delivery dan Services.

Responden : Pembelian, Logistik, Quality

Control, Gudang dan Keuangan.

Hasil kuisioner dapat dilihat pada Tabel 3.2, maka hasil perhitungannya adalah sebagai berikut:

Total Cost untuk SP_001

$=4+4+5+4+4=21$

Total Cost untuk SP_002

$=4+3+4+4+3=18$

Total Cost untuk SP_003

$=3+4+3+4+3=17$

Maka nilai rata-rata per item untuk variabel

Cost SP_001 $=21 / 5=4.20$.

Cost SP_002 $=18 / 5=3.60$.

Cost SP_002 $=17 / 5=3.40$.

Sedangkan nilai rata-rata per variabel

$=($ SP_001 + SP_002 + SP_003 $) / 3$

$=(4.20+3.60+3.40) / 3$

$=11.20 / 3$

$=3.73$ (bulatkan jadi 4)

Dengan cara yang sama dilakukan untuk perhitunan variabel quality, delivery dan services.

Setelah merekap hasil kuisioner dari 4 aspek yang ada maka selanjutnya adalah menghitung GAP . Perhitungan nilai GAP dilihat dari selisih antara nilai tiap aspek dengan nilai profil supplier yang diberikan, yaitu 4, 4, 4, 4yang berarti semua nilai skala untuk setiap variabel yang digunakan sebagai standar penilaian adalah nilai 4 (kategori baik)[7]. Proses perhitungan Nilai GAP adalah sebagai berikut:

Nilai GAP untuk setiap item dalam variabel per supplier dapat di hitung dengan menggunakan ketentuan sebagai berikut:

1. Apabila nilai kuisioner sama dengan nilai profil maka nilai GAP adalah 0 .

2. Apabila nilai kuisioner satu digit di atas nilai profil maka nilai GAP adalah 1 .

3. Apabila nilai kuisioner satu digit di bawah nilai profil maka nilai GAP adalah -1.

Berdasarkan ketentuan tersebut nilai GAP untuk setiap item dalam variabel per supplier adalah sebagai berikut:

ID Supplier SP_001 pada variabel Cost :

Nilai Kuisioner : 4

Nilai Profil : 4

Nilai Gap : $\quad 0$

Tabel 2. Perhitungan Nilai GAP

\begin{tabular}{|c|c|c|c|c|c|}
\hline $\begin{array}{c}\text { N } \\
\text { o }\end{array}$ & $\begin{array}{c}\text { ID_Suppl } \\
\text { ier }\end{array}$ & Cost & $\begin{array}{c}\text { Quali } \\
\text { ty }\end{array}$ & $\begin{array}{c}\text { Delive } \\
\text { ry }\end{array}$ & $\begin{array}{c}\text { Servic } \\
\text { es }\end{array}$ \\
\hline 1 & SP_001 & 4 & 4 & 3 & 4 \\
\hline 2 & SP_002 & 3 & 4 & 3 & 3 \\
\hline 3 & SP_003 & 3 & 3 & 3 & 3 \\
\hline \multicolumn{2}{|c|}{$\begin{array}{c}\text { Profil } \\
\text { Supplier }\end{array}$} & $\mathbf{4}$ & $\mathbf{4}$ & $\mathbf{4}$ & $\mathbf{4}$ \\
\hline 1 & SP_001 & 0 & 0 & -1 & 0 \\
\hline 2 & SP_002 & -1 & 0 & -1 & -1 \\
\hline 3 & SP_003 & -1 & -1 & -1 & -1 \\
\hline
\end{tabular}

Setelah merekap hasil kuisioner dari 4 aspek yang ada maka selanjutnya adalah menghitung GAP . Perhitungan nilai GAP dilihat dari selisih antara nilai tiap aspek dengan nilai profil supplier yang diberikan, yaitu 4, 4, 4, 4. Proses perhitungan Nilai GAP dapat dilihat pada Tabel 2

Tabel 3 Perhitungan Nilai Bobot

\begin{tabular}{|l|l|r|r|r|r|}
\hline No & \multicolumn{1}{|c|}{$\begin{array}{l}\text { ID_Suppli } \\
\text { er }\end{array}$} & \multicolumn{1}{c|}{ Cost } & \multicolumn{1}{c|}{$\begin{array}{c}\text { Quali } \\
\text { ty }\end{array}$} & \multicolumn{1}{c|}{$\begin{array}{c}\text { Deliv } \\
\text { ery }\end{array}$} & \multicolumn{1}{c|}{$\begin{array}{c}\text { Servi } \\
\text { ces }\end{array}$} \\
\hline 2 & SP_001 & 4 & 4 & 3 & 4 \\
\hline 3 & SP_002 & 3 & 4 & 3 & 3 \\
\hline Profil Supplier & & 3 & 3 & 3 & 3 \\
\hline 1 & SP_003 & 4 & 4 & 4 & 4 \\
\hline Pembobotan & & 0 & 0 & -1 & 0 \\
\hline 2 & SP_002 & -1 & 0 & -1 & -1 \\
\hline Pembobotan & & 5 & 5 & 4 & 5 \\
\hline 3 & SP_003 & -1 & -1 & -1 & -1 \\
\hline Pembobotan & & 4 & 5 & 4 & 4 \\
\hline
\end{tabular}

Setelah menentukan bobot nilai gap untuk tiap aspek yang ada dalam kriteria, maka langkah berikutnya adalah mengelompokkan tiap kriteria dalam 4 aspek 
menjadi 2 kelompok "Core Factor " dan "Secondary Factor", di mana cost dan quality menjadi core factor dan delivery dan services ke dalam secondary factor. Setelah memisahkan kedalam 2 kelompok, selanjutnya adalah menghitung core factor dengan persamaan 1 .

$$
N C F=\frac{\sum N C(i, s, d)}{\sum I C}
$$

Di mana:

$\mathrm{NCF}=$ Nilai rata-rata core factor

$\mathrm{NC}(\mathrm{i}, \mathrm{s}, \mathrm{p})=$ Jumlah total nilai core factor

IC = Jumlah item core factor

Perhitungannya adalah sebagai berikut :

SP_001:

Nilai Bobot Cost $=5$

Nilai Bobot Quality $=5$

$\mathrm{NC}=2$

Maka Nilai NCF untuk SP_001 $=(5+5) / 2=5$

Dan menghitung secondary factor dengan persamaan 2.

$$
N S F=\frac{\sum N S(i, s, d)}{\sum I S}
$$

Di mana:

NSF = Nilai rata-rata secondary factor

$\mathrm{NS}(\mathrm{i}, \mathrm{s}, \mathrm{p})=$ Jumlah total nilai secondary factor

IS = Jumlah item secondary factor

Perhitungannya adalah sebagai berikut :

SP_001:

Nilai Bobot Delivery $=4$

Nilai Bobot Services $=5$

IS $=2$

Maka Nilai NSF untuk SP_001 $=(4+5) / 2=4.5$

\begin{tabular}{|c|c|c|c|c|c|c|c|}
\hline \multicolumn{2}{|c|}{$\begin{array}{l}\text { Profil } \\
\text { Supplier }\end{array}$} & \multicolumn{4}{|c|}{ Factor } & \multirow[t]{2}{*}{$\begin{array}{l}\text { Zore } \\
\text { Factor } \\
\end{array}$} & \multirow[t]{2}{*}{$\begin{array}{l}\text { Secondary } \\
\text { Factor } \\
\end{array}$} \\
\hline 1 & SP_001 & 0 & 0 & -1 & 0 & & \\
\hline \multicolumn{2}{|c|}{ Pembobotan } & 5 & 5 & 4 & 5 & 5 & 4.5 \\
\hline 2 & SP_002 & -1 & 0 & -1 & -1 & & \\
\hline \multicolumn{2}{|c|}{ Pembobotan } & 4 & 5 & 4 & 4 & 4.5 & 4 \\
\hline 3 & SP_003 & -1 & -1 & -1 & -1 & & \\
\hline & bobotan & 4 & 4 & 4 & 4 & 4 & 4 \\
\hline
\end{tabular}

Tabel 4 Hasil Perhitungan Core dan Secondary

Dari perhitungan setiap kriteria dari 4 aspek yang diatas, berikutnya dihitung nilai total berdasarkan presentase dari core factor dan secondary factor yang diperkirakan berpengaruh terhadap pemilihan supplier bahan kimia terbaik. Penghitungan nilai total menggunakan persamaan 3 .

$(x) \% \cdot N C F(i, s, p)+(x) \% \cdot N S F(i, s, p)=N(i, s, p)$

Keterangan:

NCF : Nilai rata-rata core factor

NSF : Nilai rata-rata secondary factor
$\mathrm{N}$ : Nilai total dari aspek

(x)\% : Nilai persen yang diinputkan

Perhitungannya adalah sebagai berikut :

SP_001:

Nilai $\mathrm{NCF}=5$

Nilai NSF $=4.5$

Bobot $\mathrm{NCF}=65 \%$.

Bobot NSF $=35 \%$.

Maka selanjutnya dilakukan perhitngan nilai bobot untuk setiap variabel sebagi berikut :

$\mathrm{NC}($ Nilai Cost $)=(65 \% * 5)+(35 \% * 4.5)$

$$
=3.25+1.575=4.8
$$

\begin{tabular}{|c|c|c|c|c|c|c|c|}
\hline $\begin{array}{l}\text { Profil } \\
\text { Supplier }\end{array}$ & 4 & 4 & 4 & 4 & $\begin{array}{l}\text { Core } \\
\text { Factor }\end{array}$ & $\begin{array}{l}\text { Secondary } \\
\text { Factor }\end{array}$ & $\begin{array}{l}\mathbf{N} \\
\mathbf{C}\end{array}$ \\
\hline \begin{tabular}{l|l}
1 & SP_001
\end{tabular} & 0 & 0 & -1 & 0 & & & \\
\hline Pembobotan & 5 & 5 & 4 & 5 & 5 & 4.5 & 4.8 \\
\hline \begin{tabular}{l|l}
2 & SP_002
\end{tabular} & -1 & 0 & -1 & -1 & & & \\
\hline Pembobotan & 4 & 5 & 4 & 4 & 4.5 & 4 & 4.3 \\
\hline \begin{tabular}{l|l}
3 & SP_003
\end{tabular} & -1 & -1 & -1 & -1 & & & \\
\hline Pembobotan & 4 & 4 & 4 & 4 & 4 & 4 & 4 \\
\hline
\end{tabular}

Tabel 5 Perhitungan Nilai Total

proses profile matching adalah ranking

dari kandidat yang diajukan untuk mengisi suatu jabatan tertentu. Penentuan ranking mengacu pada hasil perhitungan dengan persamaan 4 .

Ranking $=$

$(x) \% . N c(i, s, p)+(x) \% . N q(i, s, p)+N d(i, s, p)+N s(i, s, p)$

Keterangan:

$$
\begin{aligned}
& \mathrm{Nc}: \text { Nilai Cost } \\
& \mathrm{Nq}: \text { Nilai Quality } \\
& \mathrm{Nd}: \text { Nilai Delivery } \\
& \mathrm{Ns} \text { : Nilai Service }
\end{aligned}
$$

Perhitungannya adalah sebagai berikut:

Bobot $\mathrm{Nc}=40 \%$

Bobot $\mathrm{Nq}=25 \%$

Bobot $\mathrm{Nd}=25 \%$

\begin{tabular}{|c|c|c|c|c|c|c|c|}
\hline No & $\begin{array}{c}\text { ID_Suppli } \\
\text { er }\end{array}$ & $\underset{(40 \%)}{\mathrm{Nc}}$ & $\underset{(25 \%)}{\mathbf{N q}}$ & $\begin{array}{c}\text { Nd } \\
(20 \%)\end{array}$ & $\begin{array}{c}\text { Ns } \\
(15 \%)\end{array}$ & $\begin{array}{l}\text { Hasil } \\
\text { Akhir }\end{array}$ & $\begin{array}{c}\text { Peri } \\
\text { ngk } \\
\text { at }\end{array}$ \\
\hline 1 & SP_001 & 4,8 & 4,3 & 4,6 & 4 & 4,515 & 1 \\
\hline 2 & SP_002 & 4,3 & 3,8 & 3,6 & 4 & 3,99 & 2 \\
\hline 3 & SP_003 & 4 & 3,6 & 4 & 3,8 & 3,87 & 3 \\
\hline
\end{tabular}

Bobot Ns $=15 \%$

Hasil Akhir SP_001

$=(40 \% * 4,8)+(25 \% * 4,3)+(20 \% * 4,6)+(15 \% * 4)$

$=1.92+1.075+0.92+0.6$

$=4.515$

Tabel 6 Perangkingan Supplier

Berdasarkan hasil perhitungan di atas, maka supplier terbaik untuk digunakan PT.Lautan Luas sebagai pemasok bahan kimia bagi perusahaan adalah supplier dengan ID SP_001.

\subsection{Tampilan Program}

Data yang digunakan dalam penelitian inidata hasil kuisioner yang dibagikan kepada bagian 
pembelian, logistik, quality control, gudang dan keuangan. adapun tampilan hasil implementasi pemilihan supplier terbaik dengan metode profile matching ini adalah sebagai berikut :

1. Tampilan Form Login

Form login adalah form yang digunakan untuk login masuk ke dalam aplikasi, di mana username andre dengan password supplier, selanjutnya tekan tombol OK, sehingga muncul form menu utama[5]. Adapaun tampilan form login dapat dilihat pada Gambar 1.

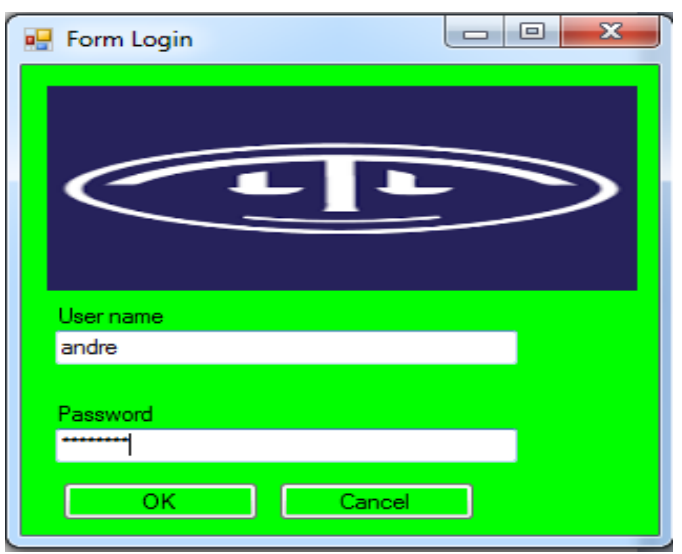

Gambar 1 Tampilan Form Login

2. Tampilan Form Menu Utama

Tampilan menu utama adalah tampilan yang muncul setelah pengguna sukses melakukan login. Form menu utama ini digunakan sebagai tempat pengguna melakukan konsultasi pemilihan supplier terbaik menggunakan metode profile matching. Adapun tampilan menu utama dapat dilihat pada Gambar 2.

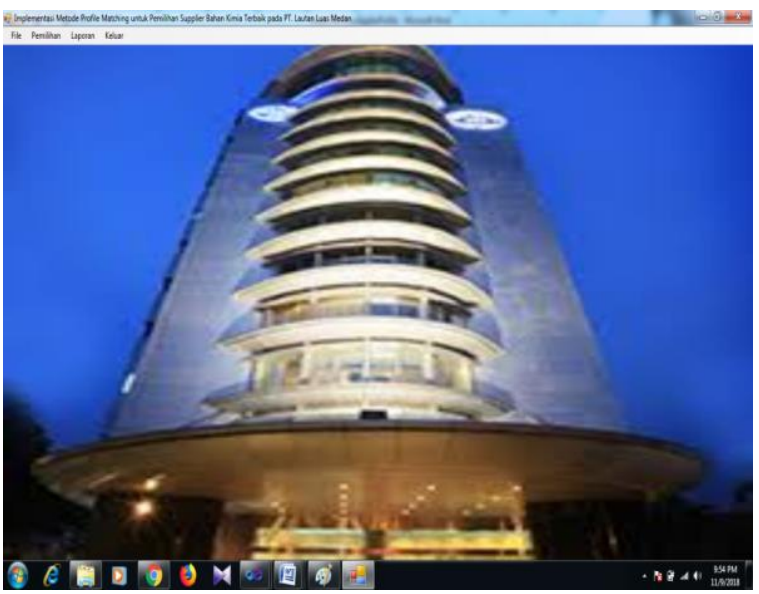

Gambar 2 Tampilan Form Menu Utama

3. Tampilan Form Supplier

Tampilan Form Supplier adalah tampilan yang muncul jika pengguna memilih menu File, lalu klik sub menu Data Supplier pada form menu utama. Form Supplier digunakan untuk melakukan proses nput data supplier ke dalam aplikasi. Form ini juga mencakup penambahan data, perubahan data, penghapusan data dari dan ke dalam aplikasi. Adapun tampilan Form Supplier dapat dilihat pada Gambar 3.

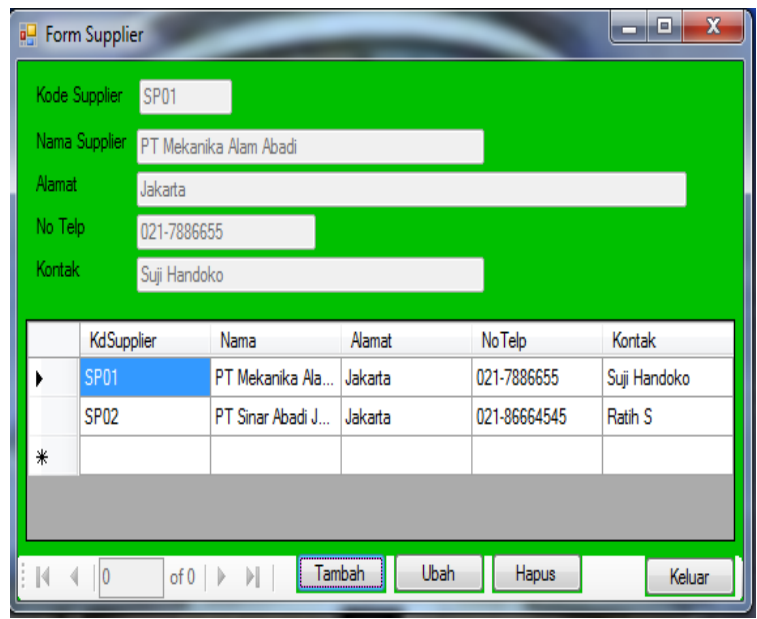

Gambar 3 Tampilan Form Supplier

4. Tampilan Form Pemilihan

Form Pemilihan adalah tampilan yang muncul jika pengguna memilih menu Pemilihan pada form menu utama. Form Pemilihan digunakan untuk melakukan proses pemilihan supplier terbaik menggunakan metode profile matching. Adapun tampilan Form Pemilihan dapat dilihat pada Gambar 4

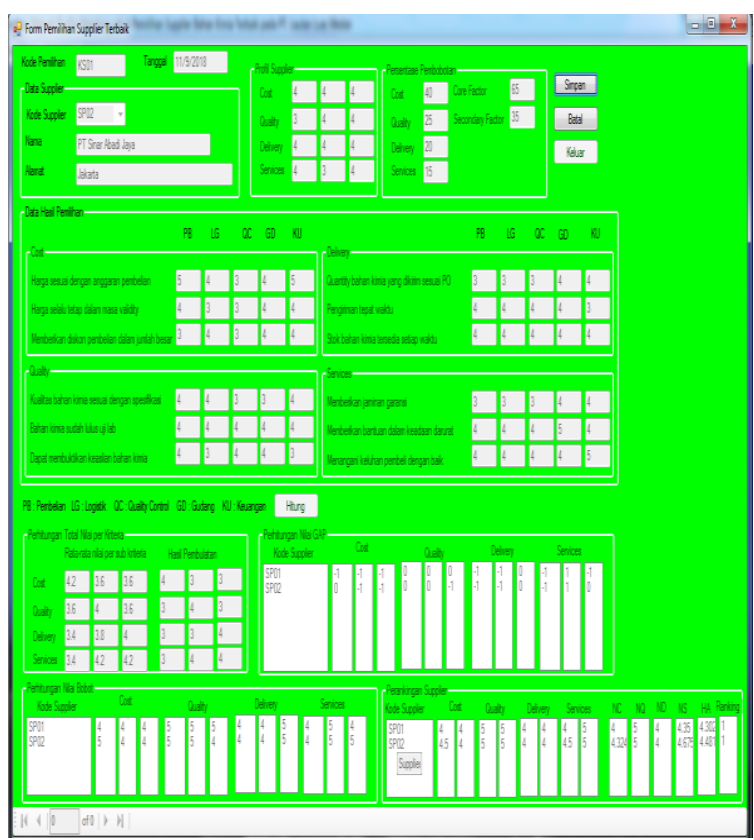

Gambar 4 Tampilan Form Pemilihan

Dari perhitungan setiap kriteria dari 4 aspek yang diatas, berikutnya dihitung nilai total berdasarkan presentase dari core factor dan secondary factor yang diperkirakan berpengaruh terhadap pemilihan supplier bahan kimia terbaik. Penghitungan nilai total menggunakan persamaan 3. 


\section{KESIMPULAN}

Berdasarkan hasil penelitian yang

dilakukan sebelumnya, maka peneliti dapat menarik kesimpulan sebagai berikut :

1. Proses kerja pemilihan supplier bahan kimia terbaik yang digunakan PT. Lautan Luas Medan masih menggunakan sistem manual berdasarkan kriteria cost, quality, delivery dan service.

2. Pemilihan supplier bahan terbaik menggunakan metode profile matching dilakukan berdasarkan nilai ranking tertinggi.

3. Metode profile matching dapat diterapkan untuk pemilihan supplier bahan kimia terbaik sehingga dapat membantu manajemen perusahaan dalam menentukan supplier yang akan digunakan dalam memasok bahan kimia bagi perusahaan.

\section{UCAPAN TERIMA KASIH}

Penulis mengucapkan terima kasih kepada Universitas Prima Indonesia Medan, Dosen Pembimbing, yang telah memberikan kesempatan dan dukungan sehingga penelitian ini dapat terselesaikan dengan baik.

\section{DAFTAR PUSTAKA}

[1] Herjanto,Eddy.2008.Manajemen Operasi.Grasindo. Jakarta.

[2] Kusrini. 2007, Konsep dan Aplikasi Sistem Penunjang Keputusan, Yogyakarta : Andi Offset

[3] Nofriansyah, Dicky, Konsep Data Mining Sistem Pendukung Keputusan. deepublish. Sleman.2014

[4] Delfmann, W., \& Klaas-Wissing, T. , 2007 , Strategic Supply Chain Design: Theory, Concepts, and Applications, Kölner Wissenschaftsverlag, koln.

[5] Winda Sulistiana., 2013, Analisis Pemilihan Supplier Bahan Baku Dengan Menggunakan Metode Fuzzy Analytical Hierarchy Process (FAHP), Skripsi S-1, Institut Teknologi Adhi Tama, Surabaya : http://jurnal.itats.ac.id/wpcontent/uploads/2 013/02/Analisis-Pemilihan-Supplier-B Menggunakan-Metode-Fuzzy-AnalyticalHierarchy-Process-FAHP.pdf [3 september 2013].

[6] Sartin., 2009, Pemilihan Supplier Bahan Baku Dengan Menggunakan Metode Multi Criteria Decision Making (Mcdm) With
Promethee Dan Goal Programming Diperusahaan Azam Jaya Sidoarjo, Skripsi S-1, UPN Veteran Jawa Timur, Surabaya : http://ejournal.upnjatim.ac.id/index.php/tek mapro/article/download/309/254 [3September 2013]

[7] Supranto, Johannes., 2005, Teknik Pengambilan Keputusan, PT Rineka Cipta, Jakarta.

[8] Sri Kusumadewi., 2006, Fuzzy Multi Attribute Becision Making (Fuzzy MADM), Graha Ilmu Yogyakarta.

[9] Darmawan, A. S. (2012). Metode Profile Matching. Jurnal Ilmiah ICTech, 10(1), 1-5.

[10] Faizal, E. (2014). Implementasi Metode Profile MIK El Rahma. Journal Speed, 6(1), 60-65. 